\title{
Ponadczasowa wartość i atrakcyjność pedagogicznego przesłania czcigodnego Sługi Bożego kardynała Stefana Wyszyńskiego
}

Dysponując szczegółowymi analizami obszernego materiału badawczego, jakim jest pisarska i homiletyczna spuścizna Prymasa Tysiąclecia ${ }^{1}$,

Por. A. Rynio, Wychowanie młodzieży w nauczaniu Kardynała Stefana Wyszyńskiego, Lublin 2001 wyd. II; A. Rynio, Społeczne wychowanie osoby w nauczaniu Prymasa Tysiąclecia, w: Pedagogika katolicka. Zagadnienia wybrane, red. A. Rynio, Stalowa Wola 1999, s. 215-242; A. Rynio, Wychowanie patriotyczne w nauczaniu Kard. S. Wyszyńskiego, w: Wychowanie do patriotyzmu, red. W. Janiga, Przemyśl-Rzeszów 2006, s. 719-737; A. Rynio, Mądre wychowanie patriotyczne przedmiotem troski Prymasa Tysiąclecia, „Studia Prymasowskie UKSW" 4 (2011), s. 247-264; A. Rynio, Cele wychowania młodzieży w nauczaniu Prymasa Tysiąclecia. Analiza pedagogiczna w świetle Prawa i Przyrzeczenia Harcerskiego, w: Wychowanie chrześcijańskie metodą harcerską, red. A. Petkowicz, Lublin 2009, s. 211-223; A. Rynio, Myśl pedagogiczna Stefana Kardynała Wyszyńskiego, w: Stefan Kardynał Wyszyński (1901-1981). Myśl społeczna, red. S. Fel, M. Wódka, Lublin 2017, s. 47-70, A. Rynio, Rodzina jako Kościót domowy w nauczaniu Kard. Stefana Wyszyńskiego, w: Rodzina jako Kościół domowy, red. A. Tomkiewicz, W. Wieczorek, Lublin 2010, s. 115-131; A. Rynio, Samowychowanie metoda skutecznego wychowania w nauczaniu Kardynała Stefana Wyszyńskiego, „Roczniki Nauk Społecznych" 23 (1995), z 2, s. 27-43, A. Rynio, Społeczne wychowanie młodzieży w nauczaniu 
w niniejszym przedłożeniu chcę jedynie przywołać kilka argumentów potwierdzających obiektywną ponadczasową wartość i atrakcyjność prymasowskiego przesłania pedagogicznego. Dążąc do syntetycznego spojrzenia na aktualność i atrakcyjność prymasowskiej myśli pedagogicznej, przede wszystkim zwrócę uwagę na to, jakim człowiekiem i nauczycielem był prymas Stefan Wyszyński, jak rozumiał istotę wychowania, gdzie tkwi geneza takiego sposobu pojmowania fenomenu wychowania, jakie funkcje mu przypisywał, wreszcie co ma do zaproponowania współczesnym teoretykom i praktykom tej dziedziny.

Jakkolwiek ograniczone ramy mojej wypowiedzi nie pozwalają w sposób analityczny odpowiedzieć na wszystkie wyżej postawione pytania, to jednak wydaje się, że wobec zauważanego dziś kryzysu wychowania i braku równowagi między wolnością a świadomością etyczną, między władzą a sumieniem, między postępem technologicznym a postępem społecznym nawet połowiczna znajomość integralnej wizji wychowania dzieci i młodzieży kard. Stefana Wyszyńskiego nabiera szczególnej wagi i znaczenia, Szczególnie, że oczekujemy na Jego rychłą beatyfikację, a osoby zainteresowane bardziej analitycznymi opracowaniami można odesłać do tych, które już istnieją. W sytuacji braku uszczegółowionych analiz cennym źródłem ukierunkowującym może być zaś wyjątkowo bogata dwutomowa bibliografia Mariana Piotra Romaniuka Prymas Tysiaclecia w stowie pisanym powstała w ramach realizacji Centralnego Projektu Badawczego IPN².

\footnotetext{
Prymasa Tysiaclecia jako warunek przetrwania narodu i kultury, w: O społeczeństwie, wychowaniu i pracy w myśli Kardynała Stefana Wyszyńskiego, red. L. Marszałek, A. Solak, Warszawa 2010, s. 79-100; A. Rynio, Wychowanie do odpowiedzialności za naród w Kazaniach Millenijnych Kardynała Stefana Wyszyńskiego, „Summarium” 34-35 (1985-86), s. 229-239; A. Rynio, Znaczenie rodziny w chrześcijańskim wychowaniu dzieci i młodzieży w nauczaniu Stefana Kardynała Wyszyńskiego, w: Rodzina - historia i wspótczesność, red. B. Kiereś, M. Gromek, K. Hryszan, Lublin 2018, s. 137-152 (Pedagogika Rodziny w Teorii i Praktyce, 6).

2 M. P. Romaniuk, Prymas Tysiąclecia w słowie pisanym. Bibliografia życia, twórczości i postugi Kardynała Stefana Wyszyńskiego 1921-2017, Warszawa 2018.
} 


\section{Atrakcyjności przesłania i jego geneza}

Szukając odpowiedzi na pytanie o to, jakim człowiekiem i nauczycielem był prymas Stefan Wyszyński, godzi się podkreślić, iż kardynał Stefan Wyszyński przede wszystkim był prymasem, mężem stanu, pasterzem i dobrym człowiekiem. Nazywano go księciem Kościoła i przywódcą narodu, obrońcą człowieka, strażnikiem prawa i moralności. Jego wielkość polegała na tym, że nie tworząc nowej doktryny ani ideologii, splótł tradycję narodu i chrześcijański system wartości. Zbudował w ten sposób bastion nie do obalenia. $Z$ jego imieniem na wieki będzie się wiązał fakt, że Polska pozostała niezwyciężona. Kardynał we właściwy sobie sposób ustrzegł jej duchową, narodową i europejską tożsamość. To o nim św. Jan Paweł II mówił jako o człowieku „niezwykłej miary”, będącym „zwornikiem Kościoła”, a także „wielkim pasterzem i wychowawcą rodaków”, a nadto "miłośnikiem polskiej ziemi”, "policzonym za jednego z największych mężów w jej dziejach”, „stawianym ze względu na swój styl pasterzowania w towarzystwie św. Wojciecha i Św. Stanisława"3. Jan Paweł II w Liście do Narodu polskiego z 7 lipca 1981 roku, dając świadectwo niezwykłej wielkości Prymasa Tysiąclecia, wskazał na jego bogactwo ducha wyrażające się w umiłowaniu Kościoła, Ojczyzny i człowie$\mathrm{ka}^{4}$. Niewątpliwie Wyszyński, jako człowiek prawy i roztropny, a jeśli trzeba - stanowczy, wpajał swoim uczniom poczucie sprawiedliwości i prawdy. Jako wychowawca był jednostką mocną, harmonijną i kochającą, chciał być blisko tych, których nauczał, pragnął ich wzrostu, szanował ich wolność, widział ich w sposób realistyczny. Niezachwiany w działaniu i przeciwnościach, miał świadomość własnych bogactw wewnętrznych i pozytywnych wartości. Łączył w sobie mądrość działania, odpowiedzialność i służbę. W jego stylu życia widać, iż był uodporniony na cudze sądy, a równocześnie nieugodowy i nieprzejednany wobec zła. Nauczając, starał się pomagać osobom w autentycznym odkrywaniu własnych bogactw w zakresie intelektu, woli i uczucia. Od początku jego działalności duszpasterskiej i pisarskiej widoczny był wysiłek zrozumienia świata młodzieży. Kontakt Prymasa Tysiąclecia z nią był życzliwy, pełen szacunku i miłości, oparty na autorytecie

3 Por. Ojciec Święty Jan Paweł II o Kardynale Stefanie Wyszyńskim, w: Człowiek niezwykłej miary, kom. red. M. Plaskacz, A. Rastawicka, W. Wojdecki, Warszawa 1984, s. $127-140$.

$4 \quad$ Ojciec Święty Jan Paweł II o Kardynale Stefanie Wyszyńskim, dz. cyt., s. 133-134. 
moralnym i nastawiony na dawanie świadectwa prawdzie, którą się żyje bez względu na okoliczności.

Niewątpliwie zasługą prymasa Wyszyńskiego, w osobie którego mogliśmy widzieć wyjątkowego nauczyciela i męża stanu, a zarazem prekursora Soboru Watykańskiego II, jest upowszechnienie przez niego podstawy integralnego systemu pedagogicznego opartego na pełnym obrazie człowieka wychowywanego, co istotne jest tym bardziej, że sam Wyszyński nie był teoretykiem wychowania, a swoje przesłanie opierał na nauce Ewangelii i św. Tomasza przypomnianej przez o. Jacka Woronieckiego i Jacques'a Maritaina. Co więcej - w swojej koncepcji wychowawczej szedł dalej niż neotomiści pomijający wartość kultury. Duchowny pragnął ulepszyć całego człowieka, doskonaląc jego tożsamość w sposób naturalny, nie zapominając równocześnie o ludzkiej podmiotowości i zależności od Boga. Podkreślając konieczność oddziaływania na całość osobowości wychowywanych, Wyszyński tak porządkował obraz świata, człowieka, celu i sensu jego istnienia, że harmonijny rozwój osoby ludzkiej stawał się nie tylko możliwy, ale niepodważalny i oczywisty. Dokonywało się to na drodze ustawicznego budzenia wśród rodzin i młodzieży jak również wszelkich instytucji wychowujących poczucia ducha religijnego posłannictwa oraz głębokiej odpowiedzialności za religijne, a zarazem społeczne oblicze własnego życia i życia narodu.

Poszczególne elementy prymasowskiej koncepcji wychowania w dalszym ciągu stanowić mogą osobny przedmiot badań. Godna pogłębionego opracowania może być niewątpliwie kulturotwórcza funkcja wychowania, jak również sama geneza myśli Wyszyńskiego ze szczegółowym uwzględnieniem źródeł patrystycznych, a także porównanie omawianej koncepcji wychowania $z$ innymi dawnymi i współczesnymi jego teoriami.

Owoce przeprowadzonych dotychczas analiz mają charakter na tyle uniwersalny i ponadczasowy, że mogą znaleźć zastosowanie praktyczne w procesie dydaktyczno-pedagogicznych oddziaływań na dzieci, młodzież i społeczności je wychowujące. Godny podkreślenia jest też fakt, iż Wyszyński starał się patrzeć na świat ludzi młodych ich własnymi oczyma. Wykazując odpowiednią wiedzę na temat zaspokojenia potrzeb naturalnych, psychicznych i religijnych dzieci i młodzieży, nie ograniczał jednak swojej roli do kogoś, kto jedynie poucza i daje gotowe rozwiązania.

Praktyczne znaczenie prymasowskiej pedagogii, będącej pedagogią wiary, nadziei i miłości, jakkolwiek nie jest ona w pełni dającą się opisać teorią 
naukową, stanowi nader ciekawy i istotny kierunek wychowania człowieka wierzącego, który realizuje swoje człowieczeństwo w nie zawsze sprzyjających okolicznościach, co w dzisiejszych czasach nabiera wyjątkowego znaczenia.

Szczególną wartość prymasowskiego przesłania pedagogicznego należy dostrzec $w$ tym, że nie zawęża on wychowania do oddziaływania samego tylko człowieka w różnym stopniu przygotowanego do tej funkcji, ale ukazuje wychowanie jako współdziałanie wychowanka i wychowawcy z łaską Bożą. Ponadto ukazuje, jak w procesie religijnego formowania i dojrzewania człowieka można uniknąć dwutorowości polegającej na tym, iż jednym torem idzie jego myślenie i działanie religijne, innym zaś życie zawodowe i społeczne. Prymas jest za ciągłą weryfikacją Bożych prawd i wymagań z rzeczywistością, w której człowiek żyje. W tym wyraża swoje poczucie realizmu pedagogicznego.

Pedagogia prymasa jest pedagogią walki o dobro w sobie i wokół siebie przejawiającej się w pokonywaniu własnego egoizmu, służbie Bogu, bliźniemu i społeczności. Rozumiejąc wychowanie jako współpracę z człowiekiem w kolejnych fazach jego rozwoju, zwracał on uwagę na praktyczną stronę wychowania. Jakkolwiek jego pedagogia ma charakter postulatywny, to jednak nie bał się podejmować wśród młodzieży i nauczycieli tematów trudnych i niepopularnych. W duchu nauki chrześcijańskiej przekładał na język zrozumiały dla współczesnych sobie pokoleń wychowywanych i wychowujących prawdę o tym, iż nadprzyrodzoność przenika rzeczywistość świata, a stawanie się nowym, dojrzałym duchowo człowiekiem dokonuje się przy wolnym udziale własnej aktywności współpracującej z łaską Bożą zawierającą w sobie łaskę przebaczenia. Wyszyński nie ukrywał, iż droga, którą należy pokonać, ażeby stać się autentycznie sobą samym, zakłada uznanie prawdy o uwikłaniu człowieka w grzech i domaga się przyjęcia oczyszczenia, poprzez które Bóg wyzwala człowieka ze wszystkiego, co zaciemnia autentyczne oblicze ludzkiego bytu. Uczył i uświadamiał, że droga ta domaga się od człowieka ufnego zawierzenia i oddania się Bogu. Z naciskiem podkreślał też, iż nie ma wychowania człowieka i ludzkości bez odnowy moralnej opartej na przebaczeniu, pokucie i osobistym nawróceniu, będącym odwróceniem się od tego wszystkiego, co zaciemnia Boży obraz w człowieku i czyni go bezwolnym. W rozumieniu prymasa nie da się laboratoryjnie zbadać i przełożyć na język empirii procesu stawania się wolnym 
i odpowiedzialnym na drodze wychowania, uwzględniając konieczność adekwatnej interpretacji istnienia człowieka i świata. Rozumienie to może natomiast stanowić źródło inspiracji, wskazań i hipotez badawczych dla psychologów, socjologów, teologów i pedagogów, akceptujących szczególną wartość osoby rozumianej jako podmiot i cel, postulujących wszechstronny rozwój osobowości.

Widząc potrzebę wypracowywania właściwej koncepcji wychowania, doceniającej wszystko to, co składa się na ludzkie doświadczenie, przed współczesnymi sobie myślicielami Wyszyński stawiał wyzwanie w postaci zagrożonego zarówno od strony teoretycznej, jak i praktycznej człowieczeństwa. Domagając się pełnego zrozumienia osoby ludzkiej zdolnej do samostanowienia i odpowiedzialnego uczestnictwa, ratując zagrożoną istotę człowieka, wskazywał na konsekwencje antypersonalistycznego i antyreligijnego myślenia o nim i o jego relacjach interpersonalnych i wspólnotowych. Pokazywał tym samym, iż teologiczno-pastoralny punkt widzenia problemu, jakim jest wychowanie dzieci i młodzieży, może też tworzyć konkretne problemy dla psychologii pastoralnej, szczególnie tej, która pozostaje w nurcie psychologii egzystencjalno-humanistycznej i personalistycznej ${ }^{5}$.

Niewątpliwą zasługą Prymasa Tysiąclecia jest praktyczne ukazanie motywacyjnej, modelowo wzorczej i sprawczej funkcji religijności stanowiącej podmiotowe ustosunkowanie się człowieka wobec Boga i religii katolickiej, rozumianej jako zespół prawd, norm i form zachowania, które wyjaśniają i regulują relację zachodzącą między człowiekiem a Bogiem w wychowaniu personalistycznym. Wyszyński, wychodząc od zainteresowań i potrzeb poznawczych właściwych dla okresu młodości, wiążąc religijność z całokształtem życia psychicznego, ukazywał religię jako wartość odpowiadającą istotnym potrzebom człowieka współczesnego, jako coś bardzo pozytywnego i twórczego. W proponowanym przez niego wychowaniu chodziło o to, ażeby jak zaznaczył w roku 1980 Jan Paweł II, przemawiając w siedzibie UNESCO w Paryżu, człowiek stawał się coraz bardziej człowiekiem, ażeby bardziej „był”, nie tylko więcej „miał” - aby poprzez wszystko, co „ma”, i co

5 Pisałam o tym w sposób bardziej wyczerpujący w swojej pracy doktorskiej pt. Wychowanie młodzieży $w$ nauczaniu kardynała Stefana Wyszyńskiego opublikowanej staraniem Redakcji Wydawnictw Katolickiego Uniwersytetu Lubelskiego w 1995 roku, s. 275-306. 
„posiada”, umiał bardziej i pełniej być człowiekiem, to znaczy ażeby równocześnie umiał bardziej „być”, nie tylko „z drugimi”, ale i „dla drugich”.

Wyrażona przez papieża Jana Pawła II prawda o tym, iż wychowanie ma zasadnicze znaczenie dla kształtowania stosunków międzyludzkich i społecznych, była nieobca Wyszyńskiemu, który nie przestawał zabiegać o to, aby wiara, przenikając życie we wszystkich jego wymiarach, stawała się kulturą, a człowiek, szanując prawa dane przez Stwórcę każdemu stworzeniu, budował świat w jedności i braterstwie i zasłużył na miano Syna Bożego, który realizuje swoją pełnię we wspólnocie dzieci Bożych i jedności z całym stworzeniem. Tak formułowane zasady wychowawcze, którymi człowiek winien się kierować $\mathrm{w}$ życiu osobistym, rodzinnym i społecznym, zmierzały do zrodzenia w wychowywanym nowej świadomości samego siebie. Jej treścią miało być całkowite, świadome i upragnione przylgnięcie do uprzedzającego człowieka Bożego planu i przeżywania czasu, przestrzeni i kontaktów międzyludzkich ze świadomością tej przynależności. W istocie prymasowskie rozumienie wychowania, uwzględniając całość wchodzących w nie czynników, zaprawiając do otwarcia się ku wszystkich wchodzących w grę elementów koniecznych do adekwatnej interpretacji własnego istnienia $\mathrm{i}$ istnienia świata, pomagać miało w urzeczywistnieniu pełnego człowieczeństwa wychowywanych i wychowujących. Nic więc dziwnego, iż tak rozumiane wychowanie w zakresie wartości, ideałów, norm i zasad, a także metod i środków, stanowi wartość ponadczasową godną nie tylko poznania, upowszechniania, ale i wykorzystania. Należy pamiętać, iż sposób jego realizacji zależny od warunków i czasów, w jakich proces wychowania przebiega, może być bardzo różny. Wynika to $\mathrm{z}$ faktu, iż cel prymasowskiego wychowania, odpowiadając potrzebom człowieka ochrzczonego i obywatela konkretnej społeczności, ściśle związany jest z sytuacja indywidualną, społeczną, historyczną i narodową. Pamiętać też należy, że wypowiedzi prymasa odnośnie do wychowania powstały na bazie praktyki wychowawczej rozumianej jako pewna sztuka. Nie przeszkadzało to jednak Wyszyńskiemu w czynieniu z doświadczeń pedagogicznych przedmiotu rozważań filozoficzno-teologicznych i wskazywania kierunku reform ważnych dla

6 Jan Paweł II, Wychowanie jest pierwszym i zasadniczym zadaniem kultury. Przemówienie w siedzibie Organizacji Narodów Zjednoczonych do spraw Oświaty, Nauki i Kultury [UNESCO], Paryż 2 czerwca 1980, w: Wychowanie w nauczaniu Jana Pawła II (1978-1999), red. A. Wieczorek, Warszawa 2000 s. 130. 
praktyki wychowawczej. W rozważaniach tych dominuje pytanie o to, kim jest człowiek, jaka jest jego istota, jakie są jego zadania, ku czemu powinien ukierunkowywać swoje życie. Przedstawiając jasny obraz człowieczeństwa, prymas uczył patrzeć na rzeczy doczesne w świetle ich sensu ostatecznego. W jego refleksji chodziło o wszechstronną analizę przedmiotu wychowania, jakim jest człowiek, który dzięki wychowaniu staje się samym sobą, a więc bytem bardziej wolnym i odpowiedzialnym.

Nauczanie prymasowskie, odnosząc się krytycznie do redukcjonistycznych teorii wychowania jednostki i wnosząc kategorię osoby, w której łączy się element metafizyczny z filozofią wychowania, miało inspirujący wpływ na dyskusje odnośnie do tego, co składa się na treść wychowania dzieci i młodzieży, a także na ich wybory i postawy. Nauczaniu temu, jak się wydaje, przyświecał praktyczny i bardzo konkretny cel. Było nim kreślenie wizji wychowawczej, dydaktycznej i kulturalnej dla dzieci i młodzieży, tak aby mogły one budować swe własne życie, a także osobistą, społeczną, zawodową i powołaniową tożsamość w poczuciu swobody i odpowiedzialności. Wizja ta uwzględniała analizę sytuacji przeżywanej przez dzieci i młodzież, wybór celów, dobór odpowiednich treści, metod i środków, jak również potrzebę jednolitej i normatywnej płaszczyzny odniesienia. Niewątpliwie sprzyjało to popularyzacji pewnych idei i budowaniu jednolitego sposobu myślenia o wychowaniu, wartościach, celach i normach. Chroniło też przed popadaniem w anomię i pomagało tworzyć wspólną płaszczyznę myślenia i działania, budząc indywidualne poczucie odpowiedzialności za wychowanie dobrych chrześcijan i obywateli.

\section{Aktualność prymasowskiej wizji wychowania}

Mając na uwadze aktualność prymasowskiej koncepcji wychowania, należy ją widzieć szczególnie na płaszczyźnie preferowanych przez niego celów, zasad, form i metod wychowawczych, wynikających z określonej integralnej wizji osoby ludzkiej. Zakładały one współpracę między wychowującym i wychowywanym. Prymasowskie cele i metody można sprowadzić do informowania, formowania i inspirowania, zaś praktyka łączenia prawd teologicznych z filozoficznymi nakłaniała do działania opartego na wolności, 
prawdzie i dobru. Jedną z dróg realizowania wychowania kardynał Wyszyński upatrywał w uodpornieniu człowieka na nieprawdę, zło i brzydotę i nauczeniu go rzetelnego odróżniania wartości od tego, co jest jej zaprzeczeniem. Ucząc samodzielnego myślenia i właściwego wartościowania, nie pozostawiał słuchaczy z wątpliwościami. Nawiązywał do niezniszczalnych wartości ludzkich wiążących rozum, wolę i serce. W stosunkach ludzkich radził „zwyciężać siebie samego”. Okazując niezwykłą wrażliwość na człowieka na każdym etapie jego życia, w wychowaniu nakazywał wprowadzać go w przestrzeń tego co piękne, dobre i prawdziwe. W tak rozumianym wychowaniu upatrywał znamię prawdziwego człowieczeństwa ${ }^{7}$. Przez umiejętne nakierowanie zainteresowań młodego człowieka zalecał też tworzyć w nim nietolerancję dla zła i nakłaniać do dokonywania dobrych wyborów. Według prymasa dzieje się to nie tyle na drodze karcenia, lecz zachęty, przychylności i ukazywania wzorów osobowych.

Ponadczasowość prymasowskiej refleksji na temat wychowania tkwi jednak nade wszystko $\mathrm{w}$ jego postawie poznawczej wyrażającej się $\mathrm{w}$ realizmie, personalizmie i profetyzmie. Przejawem realizmu jest uwzględnienie realności rzeczywistości doczesnych, w tym również wychowania, które traktował jako przedmiot refleksji antropologicznej, ontologicznej, etycznej i teologicznej. Wychowanie rozpatrywane zarówno ogólnie, jak i bardzo konkretnie, jednostkowo, w całym wymiarze egzystencjalnym, zostało umieszczone przez prymasa w kontekście realnych tajemnic Boga, Kościoła i wydarzeń zbawczych. Tak rozumiane, dzięki swojemu charakterowi dopełniającemu, służebnemu i zbawczemu, jest odzwierciedleniem działania stwórczego Boga, poprzez które osoba ma udział w kreacyjnym przeobrażaniu siebie i świata ${ }^{8}$.

W prymasowskiej wizji wychowanie pozostaje też w relacji z powołaniem ogólnoludzkim, a zarazem jest czymś bardzo odrębnym i indywidualnym. Człowiek przygotowuje się poprzez nie do realizacji swojego życiowego powołania, które ma spełnić zgodnie z Bożym zamysłem. Wychowanie podejmowane w kategoriach powołania, mając wymiar doskonałościowy, staje

\footnotetext{
7 Por. R. Kadziński, Nauczyciel nauczycieli, „Ład” 32 (101) (1983), s. 5.

8 Por. A. Rynio, Wychowanie młodzieży w nauczaniu kardynała Stefana Wyszyńskiego, dz. cyt., s. 301.
} 
się zadaniem, zasadą i szansą odnowy osoby odczytującej swoją wyjątkową wartość 9 .

Ponadto w omawianym nauczaniu wyjątkowość wychowania widziana była w fakcie jego służebnej funkcji dla określenia osobowości wychowywanego. Nie tylko określała ona jego osobowość, ale miała na celu doprowadzenie człowieka do zajęcia własnej zarezerwowanej wyłącznie dla niego pozycji. Chodziło o to, aby człowiek mógł podjąć swoje zadanie w sposób odpowiedzialny. Takie ujęcie wychowania wynikało z jego służebnej roli wobec prawdy, a szczególnie prawdy o człowieku. Ponadto w rozumieniu Prymasa Tysiąclecia wychowanie pełniło też funkcję ogniwa więzi społecznej i historycznej, będąc równocześnie czynnikiem rozwoju i postępu cywilizacyjnego każdego człowieka żyjącego pod każdą szerokością geograficzną i w każdych warunkach.

Nie bez znaczenia dla aktualności prymasowskiego przesłania pedagogicznego jest też jego interpretacja w duchu personalizmu chrześcijańskiego. W prymasowskim sposobie rozumienia wychowania podkreślana jest specyfika wzrastania człowieczeństwie ze świadomością tego, „kim się jest i kim być się powinno". W świadomości tak zorientowanej tkwi siła osoby, jej ideał i to, co do niego prowadzi. Równocześnie interpretacja ta zabezpiecza przed fałszywą apoteozą człowieka i jego możliwościami. Ambiwalentny charakter wychowania - źródła wolności lub alienacji, szczęścia lub tragedii, prawdy lub fałszu - pozostaje w ścisłym związku z dramatem człowieka. Wydaje się, że to właśnie ukierunkowało myśl pedagogiczną prymasa nie tyle do przeobrażeń systemowych, ile do odnowy człowieka przy założeniu koniecznych i niezbędnych warunków istnienia ładu społeczno-moralnego. Odpowiednia jakość osobowości ludzkiej, całej społeczności, warunków społeczno-historycznych tworzą w sumie rzeczywistość, w której wychowanie jest nośnikiem elementów takich jak doskonałość bytu, życie, szczęście, rozwój i wysoka wartość ludzkiej egzystencji ${ }^{10}$.

Ważną funkcją pełnioną przez wychowanie, które zakłada wspólnotowy charakter natury osoby, jest też uspołecznienie. Człowiek uspołecznia się, tzn. staje się tym, kim być powinien, spełnia się w społeczności rodzinnej,

9 A. Rynio, Wychowanie młodzieży w nauczaniu kardynała Stefana Wyszyńskiego, dz. cyt., s. 301.

10 Por. P. Bortkiewicz, Promocja wartości pracy ludzkiej Kardynała Stefana Wyszyńskiego, Lublin 1989, [praca doktorska KUL]. 
narodowej i kościelnej. W rozumieniu Stefana Wyszyńskiego wychowanie ma wprowadzać w te kręgi społeczności, pozwalając każdemu na odnalezienie w niej właściwego miejsca dla siebie. Ma też spełnić rolę czynnika kształtującego i organizującego właściwy sposób funkcjonowania każdej $\mathrm{z}$ nich. Aby tak być mogło, wychowanie musi jednak spełniać podstawowy wymiar służby: z miłością i w miłości. Służebny charakter wychowania jest gwarancją pełnej realizacji osoby ludzkiej, zarówno w wymiarze indywidualnym, jak i wspólnotowym, i polega na dostrzeżeniu i wypełnieniu właściwych celów i zadań młodzieży, rodziny, narodu i Kościoła ${ }^{11}$.

\section{Uniwersalność głoszonych poglądów}

Na uwagę zasługują te fragmenty myśli prymasa Wyszyńskiego, które sytuują wychowanie $\mathrm{w}$ uniwersalnym, ponadnarodowym procesie dziejów i rozwoju. Tak ujmowane wychowanie służy tworzeniu więzi na wskroś uniwersalnej, zarówno pod względem czasu, jak i przestrzeni.

Warto przy tym zauważyć, iż aspekt pewnego uniwersalizmu wychowania dzieci młodzieży wyraża się nie tylko w nurcie społecznościowym charakterystycznym dla prymasa, ale znajduje swoje odzwierciedlenie także w jego refleksji teologicznej, która podkreśla charakter paschalny ludzkiego działania, nadając wychowaniu wartość zbawczą z całym uwzględnieniem nadrzędności innych, zwłaszcza sakramentalnych, środków zbawienia. Twierdzenie, że praca wychowawcza ma w sobie coś ze znaku świętego, ma pewne znamię sakramentalne i przynosi człowiekowi różnorodne dobra, łącznie z mocą zbawienia, jest niewątpliwie jedną z najbardziej oryginalnych refleksji teologicznych Wyszyńskiego. Usytuowanie wychowania w obszarze misterium paschalnego Chrystusa pozwala na odczytanie ambiwalencji zbawczej wychowania i jej kategorii paschalnej. Całą rzeczywistość ziemską, w tym również obszar wychowania, przenika logika krzyża i zmartwychwstania Jezusa Chrystusa. Stąd też wychowanie, które nosi $\mathrm{w}$ sobie znamiona trudu i męki, włączone jest $\mathrm{w}$ realizm krzyża i nie staje się wylącznie uciążliwością traktowaną w kategoriach przekleństwa, ale

11 A. Rynio, Wychowanie młodzieży w nauczaniu kardynała Stefana Wyszyńskiego, dz. cyt., s. 303 . 
wpisane jest w optymizm zmartwychwstania. Kardynał Wyszyński, wiążąc wychowanie z modlitwą i sakramentami, uważał, iż procesu tego nie można stawiać w opozycji do rzeczywistości nadprzyrodzonych, ale poprzez ofiarę i wyrzeczenie należy przygotowywać grunt dla Ewangelii, wprowadzając ją w obszar ludzkiej rzeczywistości młodych. Wychowanie odczytane przez pryzmat misterium paschalnego, podobnie jak praca, nabiera charakteru weryfikacji chrześcijańskiej prawdy o życiu, jego celu i sensie w znaczeniu ewangelicznym ${ }^{12}$.

Umieszczenie rzeczywistości wychowania w optyce ewangelicznej sprawia, że terenem oddziaływań wychowawczych jest osobowe wnętrze człowieka otwartego na eschatyczną przyszłość. Znamienne jest również to, że w myśli Wyszyńskiego nie ma miejsca na izolacjonizm treści religijnych w stosunku do realiów konkretnej rzeczywistości. Jest wręcz przeciwnie. Jedynie realna i słuszna interpretacja wychowania osadzonego w konkretnym kontekście społecznym i historycznym jest możliwa w oparciu o przesłanie ewangeliczne ${ }^{13}$.

Ponadczasowe znaczenie prymasowskiego rozumienia wychowania ujawnia się także $w$ tym, iż zawiera ono aspekt psychologiczno-moralny i społeczno-kulturowy. Widoczne jest to w ukazaniu wychowania jako zespołu działań i wysiłków człowieka zmierzających do jego dojrzałości i doskonałości psychosomatycznej, zdobycia nowych wartości intelektualnych, estetycznych i moralnych oraz pełniejszego uczestnictwa człowieka w wartościach transcendentalnych. Personalizm Wyszyńskiego sprawia, że wychowanie zdaje się mierzone wyjątkową godnością osoby ludzkiej. Wartość ta jest ukazywana jako nieustanne zadanie każdego wychowywanego i wychowującego. Wymiar społeczno-kulturowy wychowania odsłania z kolei możliwości tworzenia nowych wartości kulturowych, doskonalenia współżycia międzyludzkiego i współdziałania w kierunku odczytywania prawdy i tworzenia dobra ${ }^{14}$.

Ponadczasowa wartość tak rozumianego wychowania tkwi również w integralności podejścia i wrażliwości na wartość samego człowieczeństwa

\footnotetext{
12 A. Rynio, Wychowanie młodzieży w nauczaniu kardynała Stefana Wyszyńskiego, dz. cyt., s. 303.

13 A. Rynio, Wychowanie młodzieży w nauczaniu kardynała Stefana Wyszyńskiego, dz. cyt., s. 304.

14 A. Rynio, Wychowanie młodzieży w nauczaniu kardynała Stefana Wyszyńskiego, dz. cyt., s. 304 .
} 
oraz na wszelkie wartości ducha ludzkiego. Wychowanie to oparte jest na chrześcijańskiej koncepcji osoby i świata uznaje prawa człowieka, jego godność, wolność, suwerenność. Oparte jest na rozumie, prawie miłości i dobru osoby.

W nauczaniu Prymasa Tysiąclecia dotyczącym rzeczywistości wychowania $\mathrm{z}$ łatwością dostrzec można obecność doktryny Pawła VI o pierwszeństwie osoby nad rzeczą, etyki nad techniką, bycia nad posiadaniem i miłosierdzia nad sprawiedliwością. Czwórmian ten, będąc swoistego rodzaju antidotum na zagrożenia zewnętrzne i wewnętrzne, stanowił formułę wychodzenia z licznych kryzysów towarzyszących człowiekowi czasów Wyszyńskiego. Wskazując na potrzebę pracy i aktywizowania własnych potencjalności, prymas zakładał rozpoznanie przez człowieka istoty swego bytu i należnego mu miejsca w świecie. Prymas Tysiąclecia, korzystając z własnych życiowych doświadczeń i kładąc akcent na ludzkie działanie, uczył dobrego wykorzystania rozumu, woli i uczuć. Zakładana w warstwie celowościowej wychowania pełnia osoby, wyrażająca się w życiu opartym na odwiecznych wartościach prawdy, dobra i piękna, rozwijając sam podmiot, miała przechodzić na świat zewnętrzny, humanizując go ${ }^{15} \mathrm{i}$ czyniąc bardziej przyjaznym człowiekowi.

\section{Wychowanie uwzględniające wartość religii i wiary człowieka}

Prymas Tysiąclecia, uwzględniając wartość religii, szczególne miejsce w wychowaniu przyznawał wierze człowieka odkupionego. Miała ona przenikać całość ludzkiego doświadczenia, by stać się podstawą nowej kultury opartej na „pierwszeństwie osoby nad rzeczą i bycia nad posiadaniem”. Ponadto duże znaczenie, a nawet ponadczasowość tak rozumianego wychowania można także dostrzec $\mathrm{w}$ fakcie, iż ideał, jako siła dynamizująca wobec przeznaczenia, definiuje moralność, nie pomijając doświadczenia osobistego trudu aż po ofiarę zarówno ze strony wychowywanego, jak i wychowującego. Co więcej, wychowanie uczy przeżywania ofiary w duchu stałej pamięci

15 A. Rynio, Wychowanie młodzieży w nauczaniu kardynała Stefana Wyszyńskiego, dz. cyt., s. 305 . 
o Chrystusie, a przez to staje się elementem wyzwalającym, o ile człowiek zaangażuje w nie swoją wolność. Również ten element wychowania widziany jest przez prymasa w polu integralnej celowości i służebnego charakteru. Obszary te decydują o ponadczasowym znaczeniu wychowania, dzięki któremu człowiek widzi siebie w relacji do Boga i nie usuwając Go z życia, ocala swoją niepowtarzalną wartość. Co więcej - ocala wrażliwość na swą prawość, wolność, odpowiedzialność i nieredukowalność. Takie rozumienie wychowania, budząc świadomość własnej tożsamości, chroniło przed ubezpodmiotowieniem wychowywanych i wychowujących ${ }^{16}$. Wskazywało przy tym konkretne drogi wyjścia poprzez podejmowanie pracy nad przywróceniem właściwej wizji osoby, szkoły, rodziny, Kościoła i społeczeństwa. $\mathrm{W}$ tym też tkwi jego duże znaczenie, ponadczasowy charakter i źródło postulatów dla współczesnych psychologów, socjologów, pracowników socjalnych i pedagogów orientacji humanistyczno-personalistycznych, ujmujących człowieka jako niepowtarzalne indywiduum, świadome swoich dążeń i oczekiwań realizowanych na drodze wychowania i samowychowania.

\section{Uogólnienia i wnioski}

Podsumowując pedagogiczne przesłanie Prymasa Tysiąclecia widziane przez pryzmat jego aktualności i atrakcyjności, można powiedzieć, iż nauczanie Wyszyńskiego o wychowaniu człowieka podobnie jak nauczanie o rodzinie, narodzie, Kościele czy państwie pełne jest uwagi dla problemu rozwoju człowieka, miłości, twórczości, cierpienia i wiary. Jego nauczanie wnosi poważny wkład w poznanie młodego człowieka w różnych wymiarach jego bytowania, nie zawsze możliwych do uwzględnienia przez nauki psychologiczno-pedagogiczne. Wyszyński, pokazując złożoność i wagę diagnozy w pracy z rodziną, narodem i dziećmi i młodzieżą, uwrażliwia na ważność widzenia człowieka we wszystkich jego płaszczyznach i wymiarach. Stąd przemyślenia prymasa, pogłębiające spojrzenie na rodzinę, naród i proces wychowania człowieka, liczą się także i dziś, gdy pytania o przyszłość Polski i moralną kondycję młodego pokolenia ponownie nabierają

16 A. Rynio, Wychowanie młodzieży w nauczaniu kardynała Stefana Wyszyńskiego, dz. cyt., s. 305. 
znaczenia. Przedstawione wątki prymasowskiej koncepcji, szczególnie obecnie, wobec błędnego pojmowania celów i zadań wychowania, a także wobec ciągle groźnego pragmatyzmu, socjologizmu, intelektualizmu, woluntaryzmu i wielu innych „-izmów” na gruncie wychowania mogą stanowić źródło inspiracji do nowych poszukiwań i przemyśleń, jak również pomoc w weryfikacji istniejących i tworzonych teorii i hipotez.

Niewątpliwie w osobie prymasa Wyszyńskiego mamy do czynienia $\mathrm{z}$ umysłem syntetycznym, który $\mathrm{z}$ wielu znanych sobie elementów teorii dotyczących rodziny, narodu, państwa i wychowania tworzył harmonijną syntezę, adaptując ją do warunków polskich z wyczuciem elementów polskiej psychiki narodowej. Umiejętność syntetycznego patrzenia na świat i człowieka uwidoczniła się w nauczaniu prymasowskim na wiele lat przed Soborem Watykańskim II. Wyszyński stał na stanowisku, że doświadczenia współczesnej pedagogiki, psychologii, socjologii, polityki i kultury wskazują na to, że mądrość nowych czasów objawia się właśnie w tej umiejętności, która może zaistnieć, gdy wszystkie wartości materialne i duchowe, doczesne i wieczne, przyrodzone i nadprzyrodzone, tworzą pełną całość. To w niej widział warunek postępu, na co wskazuje dostrzeganie miejsca i roli laikatu, potrzeby odnowy liturgicznej czy wszechstronności wychowania. Umiejętność ta narastała wraz z wiekiem prymasa, dla którego droga Kościoła była zawsze drogą człowieka, a Bóg był tym, który zbawia całość ludzkiego doświadczenia. Wyszyński docierał do doświadczenia i rozszyfrowywał je, rozumiejąc i odpowiadając na rzeczywiste pytania i potrzeby sobie współczesnych. Czynił to językiem przejrzystym, świeżym, żywym i bardzo pięknym, jakkolwiek trudno jednoznacznie określić jego typ i odgadnąć, czy jest to język filozoficzny, teologiczny czy publicystyczny.

Na uwagę zasługuje też fakt, iż Wyszyński nie tylko dostrzegał złożoność sfer i zakresów wychowania fizycznego, intelektualnego, wolitywnego, emocjonalnego i moralno-religijnego, ale domagał się podporządkowania ich określonej hierarchii wartości, a nie traktowania tych zakresów równoważnie. Uważał, iż w wychowaniu należy przyznawać priorytet wartościom duchowym nad materialnymi. Z całą konsekwencją podkreślał naczelną wartość wychowania religijnego koncentrującego swą uwagę na wychowaniu osoby wiernej Chrystusowi, Kościołowi i narodowi. Tak określony cel jest osiągany przez ukierunkowanie naturalnych skłonności ku Bogu i samopoznanie odkrywające autentyczne i głęboko osadzone w fundamencie 
osoby ludzkiej wartości, jak również przez miłowanie świata i ludzi. Prowadzi to do przyjęcia całej rzeczywistości jako daru Boga Stwórcy. Wskazuje też na konieczność rozwijania w sobie otrzymanych darów przyrodzonych i nadprzyrodzonych oraz poznawania Ewangelii i czynienia z niej normatywnego orędzia dla własnego życia. Ostatecznie wszystko to miało służyć współdziałaniu z Kościołem w budowaniu Mistycznego Ciała Chrystusa. Sprzyjało temu rozwijanie świadomości własnej tożsamości i wnoszenie oryginalnej chrześcijańskiej obecności w zmieniające się okoliczności życia, czasu i przestrzeni.

Wychowaniu osobowemu przypisuje prymas rolę decydującą nie tylko w dziedzinie humanizacji czy socjalizacji, ale także w dziedzinie relacji człowieka do Boga. Można więc powiedzieć, iż w ideale wychowawczym prymasa idą w parze serce i inteligencja, umysł i uczucia, nauka i religia, idealizm i realizm, filozofia i zdrowy rozsądek, wiara i rozum, to, co dawne, i to, co współczesne, autorytet i wolność. Powrót do źródeł ewangelicznych, świadomość daru wiary, dawanie świadectwa nadziei, służba na rzecz tworzenia siebie i tworzenie wspólnoty znajdują w tym nauczaniu pełne odzwierciedlenie. Prymas nie daje jednoznacznych odpowiedzi na pytanie, co czynić, aby praca z młodzieżą przynosiła oczekiwane owoce. Zostawia ten problem otwarty i skłania wszystkich pracujących z młodzieżą do ciągłego poszukiwania przy jednoczesnym korzystaniu $\mathrm{z}$ dorobku innych. W poznaniu niebezpieczeństw zagrażających wychowaniu religijnemu młodzieży dostrzega połowę zwycięstwa. Postuluje oprzeć je na zasadzie współdziałania instytucji wychowujących i podkreśla przy tym priorytetową rolę rodziny. Podejmując zaś wychowawcze powinności Kościoła, szczególnie po Soborze Watykańskim II, zwraca uwagę na służebny charakter wspólnoty chrześcijańskiej i pokazuje, co jest jego troską, obowiązkiem i jaką rolę ma on do spełnienia. Prymas postuluje odnowę wychowania i dostosowanie je do warunków czasu i życia.

Podejmując problem wychowania dzieci i młodzieży, Wyszyński wkracza w realia życia społecznego, nie wyłączając zasad i praktyk funkcjonowania systemu społeczno-politycznego. Jego wychowanie jest wychowaniem uspołeczniającym, zatroskanym o wartości duchowe i obyczajowe narodu. Uwzględnia prawdę i doświadczenie życiowe. Czasami jednak daje się zauważyć rozbieżność między prymasa wyobrażeniami o młodzieży, a stanem faktycznym. Sprawą dyskusyjną pozostaje, w jakim stopniu proponowane przez prymasa ideały, cele i sposoby ich osiągania, były aprobowane przez 
samą młodzież. Nie stanowi to jednak dostatecznej podstawy do zanegowania wniosków pedagogiczno-psychologicznych S. Wyszyńskiego, gdyż w wychowaniu częściej istotne jest samo sformułowanie problemu niż jego rozwiązanie. To, co powiedziano powyżej, oznacza, że w analizowanych wypowiedziach, podobnie jak w encyklice Divini illius Magistri o chrześcijańskim wychowaniu papieża Piusa XI, zawarty jest konkretny osąd proponowanych ujęć wychowania, które pozostawały w opozycji do nauczania prymasa $^{17}$.

Co więcej, Wyszyński, czerpiąc z prawd objawionych zawartych w Piśmie Świętym, dokumentach Urzędu Nauczycielskiego Kościoła, dorobku uczonych katolickich i tradycji chrześcijańskiej, w swych wypowiedziach nie pozostawał tylko na poziomie oceny przynoszącej interpretację i wyjaśnienie błędnych ujęć misji i posłannictwa rodziny, narodu czy wychowania, ale wskazywał środki zaradcze w formie konkretnych zaleceń duszpasterskich. Szczególnie jest to widoczne w kazaniach i przemówieniach z okresu Wielkiej Nowenny ${ }^{18}$, w Listach Pasterskich Prymasa Polski ${ }^{19}$ czy w „wykładach uniwersyteckich dla duchowieństwa"20. Stanowisko Wyszyńskiego odnośnie do rodziny, narodu i wychowania nie było neutralne aksjologicznie, lecz korzeniami sięgało do jego przekonań filozoficzno-teologicznych. Dostrzegając problemy wynikające z polskiego doświadczenia społecznego, politycznego i pedagogicznego, zabarwionego filozofią marksistowską, prymas ujawniał niepokój wobec płynących stąd zagrożeń zarówno dla człowieka, rodziny, narodu, wychowania, jak i całego społeczeństwa ${ }^{21}$. Opracował też stałą metodę ich wyjaśniania. Była ona oparta na koncepcji człowieka, jego relacji do innych i do Boga. W świetle tej ostatniej rozpatrywane były przyczyny niepowodzeń wychowawczych i ustalane środki zaradcze. Ma to też swoje uzasadnienie w prymasowskiej metodzie pracy duszpasterskiej, polegającej na byciu zawsze po stronie człowieka i budowaniu go jako świątyni

17 Por. S. Wyszyński, Przewodnie myśli „Encykliki o chrześcijańskim wychowaniu młodzieży”, „Ateneum Kapłańskie” 26 (1929), s. 1-22.

18 Por. S. Wyszyński, Wielka Nowenna Tysiąclecia, Paryż 1962, S. Wyszyński, Uświęcenie pracy zawodowej, Paryż 1963.

19 Por. Listy Pasterskie Prymasa Polski 1946-1974, Paryż 1975.

20 Por. S. Wyszyński, Problem chrześcijańskiego wychowania młodzieży. Przemówienie wygłoszone podczas Wykładów uniwersyteckich dla Duchowieństwa w dniu 21 VIII 1968, tekst autoryzowany, ZN KUL 12 (1969) nr 2, s. 3-15.

21 Por. R. Kadziński, Wskazania Prymasa Tysiąclecia dla „Solidarności”, „Słowo Powszechne" 147 (1986). 
Ducha Świętego, szczególnie gdy jest ona w ruinie. Budowanie to niejednokrotnie dokonywało się z pomocą rodzenia nadziei poprzez sokratejski sposób budzenia w wychowywanych pragnienia dobra, prawdy, sprawiedliwości i piękna. Wszystko to stanowi o ponadczasowej wartości przesłania pedagogicznego Wyszyńskiego, kierowanego zarówno do pojedynczych jednostek, jak i do całych grup społecznych.

\section{Bibliografia}

Bortkiewicz P., Promocja wartości pracy ludzkiej Kardynała Stefana Wyszyńskiego, Lublin 1989 [praca doktorska KUL].

Jan Paweł II, Wychowanie jest pierwszym i zasadniczym zadaniem kultury. Przemówienie w siedzibie Organizacji Narodów Zjednoczonych do spraw Oświaty, Nauki i Kultury [UNESCO], Paryż 2 czerwca 1980, w: Wychowanie w nauczaniu Jana Pawła II (1978-1999), red. A. Wieczorek, Warszawa 2000, s. 130-133.

Kadziński R., Nauczyciel nauczycieli, „Ład” 3 (1983), nr 32, s. 5.

Kadziński R., Wskazania Prymasa Tysiąclecia dla „Solidarności”, „Słowo Powszechne" 147 (1986).

Ojciec Święty Jan Paweł II o Kardynale Stefanie Wyszyńskim, w: Człowiek niezwykłej miary, kom. red. M. Plaskacz, A. Rastawicka, W. Wojdecki, Warszawa 1984, s. 127-140.

Romaniuk M. P., Prymas Tysiąclecia $w$ słowie pisanym. Bibliografia życia, twórczości i posługi Kardynała Stefana Wyszyńskiego 1921-2017, Warszawa 2018.

Rynio A., Cele wychowania młodzieży w nauczaniu Prymasa Tysiąclecia. Analiza pedagogiczna $w$ świetle Prawa i Przyrzeczenia Harcerskiego, w: Wychowanie chrześcijańskie metodą harcerska, red. A. Petkowicz, Lublin 2009, s. 211-223.

Rynio A., Mądre wychowanie patriotyczne przedmiotem troski Prymasa Tysiąclecia „Studia Prymasowskie UKSW” 4 (2011) s. 247-264.

Rynio A., Myśl pedagogiczna Stefana Kardynała Wyszyńskiego. w: Stefan Kardynał Wyszyński (1901-1981). Myśl społeczna, red. S. Fel, M. Wódka, Lublin 2017, s. 47-70. 
Rynio A., Rodzina jako Kościół domowy w nauczaniu Kard. Stefana Wyszyńskiego, w: Rodzina jako Kościót domowy, red. A. Tomkiewicz, W. Wieczorek, Lublin 1995, s. 115-131.

Rynio A., Samowychowanie metoda skutecznego wychowania w nauczaniu Kardynała Stefana Wyszyńskiego, „Roczniki Nauk Społecznych” 23 (1995), z. 2, s. 27-43.

Rynio A., Społeczne wychowanie młodzieży w nauczaniu Prymasa Tysiaclecia jako warunek przetrwania narodu i kultury, w: O społeczeństwie, wychowaniu i pracy w myśli Kardynała Stefana Wyszyńskiego, red. L. Marszałek, A. Solak, Warszawa 2010, s. 79-100.

Rynio A., Społeczne wychowanie osoby w nauczaniu Prymasa Tysiaclecia, w: Pedagogika katolicka. Zagadnienia wybrane, red. A. Rynio, Stalowa Wola 1999, s. 215-242.

Rynio A., Wychowanie do odpowiedzialności za naród w Kazaniach Millenijnych Kardynała Stefana Wyszyńskiego, „Summarium” 34-35 (1985-86), s. 229-239.

Rynio A., Wychowanie młodzieży w nauczaniu Kardynała Stefana Wyszyńskiego, Lublin 2001, wyd. II.

Rynio A., Wychowanie patriotyczne w nauczaniu Kard. S. Wyszyńskiego, w: Wychowanie do patriotyzmu, red. W. Janiga, Przemyśl-Rzeszów 2006, s. 719-737.

Rynio A., Znaczenie rodziny w chrześcijańskim wychowaniu dzieci i młodzieży w nauczaniu Stefana Kardynała Wyszyńskiego, w: Rodzina - historia i wspótczesność, red. B. Kiereś, M. Gromek, K. Hryszan, Lublin 2018, s. 137-152 (Pedagogika Rodziny w Teorii i Praktyce, 6).

Wyszyński S., Listy Pasterskie Prymasa Polski 1946-1974, Paryż 1975.

Wyszyński S., Problem chrześcijańskiego wychowania młodzieży, przemówienie wygłoszone podczas Wykładów Uniwersyteckich dla Duchowieństwa w dniu 21 VIII 1968, tekst autoryzowany, ZN KUL 12 (1969) nr 2, s. 3-15.

Wyszyński S., Przewodnie myśli „Encykliki o chrześcijańskim wychowaniu młodzieży”, „Ateneum Kapłańskie” 26 (1929), s. 1-22.

Wyszyński S., Wielka Nowenna Tysiąclecia, Paryż 1962.

Wyszyński S., Uświęcenie pracy zawodowej, Paryż 1963. 
